\title{
Sintering and Contact Damage of Spinel/Mica Composites Prepared from Alumina, Magnesia and Mica-Composition Glass Powder Mixtures
}

\author{
Seiichi TARUTA, Hiroshi YONEKURA, Sofia Saori SUZUKI, \\ Kunio KITAJIMA and Nobuo TAKUSAGAWA*
}

Department of Chemistry and Material Engineering, Faculty of Engineering, Shinshu University, 4-17-1, Wakasato, Nagano-shi 380-8553

*Asama Techno-Polis Development Organization, 1-2-6, Zaimoku-cho, Ueda-shi 386-8555

\section{アルミナ，マグネシア及びマイカ組成ガラス混合粉体から調製した スピネル/マイカ複合体の焼結挙動と接触損傷}

\author{
樽田誠一·米倉＼cjkstart寛·Sofia Saori Suzuki · 北島图夫 ·田草川信雄* \\ 信州大学工学部物質工学科, 380-8553 長野市若里 4-17-1 \\ *(財)長野県テクノ財団浅間テクノポリス地域センター，386-8555 上田市材木町 1-2-6
}

\begin{abstract}
Conventional alumina and magnesia powders were mixed with a mica-composition glass powder, compacted, and fired. A dense spinel/mica composite was obtained at a low temperature of $1200^{\circ} \mathrm{C}$ for the specimen of $20 \%$ mica-composition glass addition. The sintering was promoted by not only the dissolution of fluorine ion but also the formed liquid phase. The liquid phase allowed the volume expansion caused by the reaction between the alumina and the magnesia to be effective for densification, like a closer packing of particles. Furthermore, the liquid phase caused particle rearrangement and dissolution-precipitation. Numerous flakelike mica crystals of several micrometers separated out in the interparticle regions of the spinel. Both brittle and quasi-plastic damage modes were competitive on the surface and in the subsurface of the specimen. The bending strength was slightly decreased by Hertzian indentation. The fracture site in the post-indented specimen was a cornlike crack. However, the quasi-plasticity prevented catastrophic failure from the cornlike crack. These results indicate that the composite had flaw tolerance.
\end{abstract}

[Received September 4, 2001; Accepted January 22, 2002]

Key-words : Spinel, Mica, Composite, Sintering, Microstructure, Hertz indentation test, Contact damage, Quasi-plastic

1. Introduction

The simplest preparation method for spinel-sintered compacts is the reaction sintering of an alumina and magnesia powder mixture in air. However, dense sintered compacts are difficult to fabricate by this method.1) Therefore, the fabrication of dense sintered compacts at lower temperatures requires the synthesis of a very fine spinel powder and/or a special firing method.

On the other hand, sintering additives, such as $\mathrm{AlF}_{3}$, $\mathrm{TiO}_{2}, \mathrm{~B}_{2} \mathrm{O}_{3}+\mathrm{TiO}_{2}, \mathrm{~B}_{2} \mathrm{O}_{3}+\mathrm{LiF}$, or $\mathrm{B}_{2} \mathrm{O}_{3}+\mathrm{CaF}_{2}$, are reported to be effective for the low-temperature sintering of alumina and magnesia powder mixtures. ${ }^{2)-4)}$ Such sintering behavior is explained by the dissolution of $\mathrm{F}^{-}, \mathrm{B}^{3+}$, and $\mathrm{Ti}^{4+}$ into the spinel, which causes lattice defects. ${ }^{2-4)}$ The addition of $\mathrm{CaO}$ also enhances the densification of spinel powder through liquid-phase formation. ${ }^{5), 6)}$

We reported on the fabrication of dense spinel/mica composites by sintering powder mixtures consisting of spinel and mica-composition glass. ${ }^{7), 8)}$ The obtained composites exhibited quasi-plastic deformation dependent on the additive amount and composition of the glass powder. ${ }^{9}{ }^{\text {) }}$

In the present study, in order to fabricate dense spinel/ mica composites more simply at lower temperatures, conventional alumina and magnesia powders were used as the spinel raw materials, rather than spinel powder, mixed with mica-composition glass, which contains fluorine, compacted, and fired. The sintering behavior and contact damage of the obtained composites were investigated.

\section{Experimental procedure}

The preparation method for mica-composition (fluorophlogopite: $\mathrm{KMg}_{3} \mathrm{AlSi}_{3} \mathrm{O}_{10} \mathrm{~F}_{2}$ ) glass powder is given elsewhere. 7 , 8) The starting glass powders of alumina (AES-12,
Sumitomo Chemicals, average particle size of $0.52 \mu \mathrm{m}$ ) and magnesia (MJ-30, Iwatani Chemicals, average particle size of $0.36 \mu \mathrm{m}$ ) were mixed by ball milling. The mixing ratio of the alumina and magnesia powders corresponded to a stoichiometric spinel $\left(\mathrm{MgAl}_{2} \mathrm{O}_{4}\right)$ composition, and the additions of glass powder were 0,5 or 20 mass $\%$. The three specimens are called here the $0 \%$ specimen, the $5 \%$ specimen and the $20 \%$ specimen, respectively. The powder mixtures were calcined at $600^{\circ} \mathrm{C}$ for $1 \mathrm{~h}$, passed through a 100 mesh sieve, compacted by cold-isostatic pressing at 98 $\mathrm{MPa}$, and fired in a sealed platinum tube at $1150-1500^{\circ} \mathrm{C}$ for $2 \mathrm{~h}$.

Crystalline phases in the specimens were determined using X-ray diffractometry (XRD). The bulk densities were measured by the Archimedes method. The fracture surfaces of the sintered specimens were observed by scanning electron microscopy (SEM). The polished surfaces of the $20 \%$ specimen sintered at $1200^{\circ} \mathrm{C}$ were indented, using a $\mathrm{WC}$ ball with a $3.18 \mathrm{~mm}$ radius, at a load of $500 \mathrm{~N}$ (Hertzian indentation test), and the specimens were observed by optical microscopy with Nomarski illumination and SEM. The bending strength and post-indentation bending strength of the $20 \%$ specimen sintered at $1200^{\circ} \mathrm{C}$ were measured.

\section{Results and discussion}

\subsection{Sintering and microstructure}

The XRD results showed that the alumina and magnesia began to react to form spinel at $900^{\circ} \mathrm{C}$ in the $5 \%$ and $20 \%$ specimens and the reaction was completed at $1300^{\circ} \mathrm{C}$ for the $5 \%$ specimen and at $1200^{\circ} \mathrm{C}$ for the $20 \%$ specimen, while in the $0 \%$ specimen the reaction started at $1000^{\circ} \mathrm{C}$ and finished at $1400^{\circ} \mathrm{C}$. Thus, the reaction was promoted by the dissolution of fluorine ions into the spinel. ${ }^{2), 3), 10)}$ Mica crystals ap- 
peared at $>800^{\circ} \mathrm{C}$ in the $20 \%$ specimen, but not in the $5 \%$ specimen. However, by reheating at $1100^{\circ} \mathrm{C}$, the mica crystals separated in the $5 \%$ specimen.

The bulk densities of the obtained composites are shown in Fig. 1. The 5\% and 20\% specimens were densified rapidly in the temperature ranges of $1300-1400^{\circ} \mathrm{C}$ and 1150 $1200^{\circ} \mathrm{C}$, respectively. Dense composites were obtained at $1400^{\circ} \mathrm{C}$ for the $5 \%$ specimen and at $1200^{\circ} \mathrm{C}$ for the $20 \%$ specimen, whereas the $0 \%$ specimen was hardly densified, even at $1500^{\circ} \mathrm{C}$. Approximate relative densities of both the $5 \%$ specimen sintered at $1400^{\circ} \mathrm{C}$ and the $20 \%$ specimen sintered at $1200^{\circ} \mathrm{C}$ were $>95 \%$, as determined from the measured bulk densities and the approximately calculated theoretical densities.

One reason for this low-temperature sintering was the dissolution of fluorine ions into the spinel. ${ }^{2)-4)}$ The differential thermal analysis (DTA) of the mica-composition glass showed that mica crystals separated out at $\sim 900^{\circ} \mathrm{C}$ and that

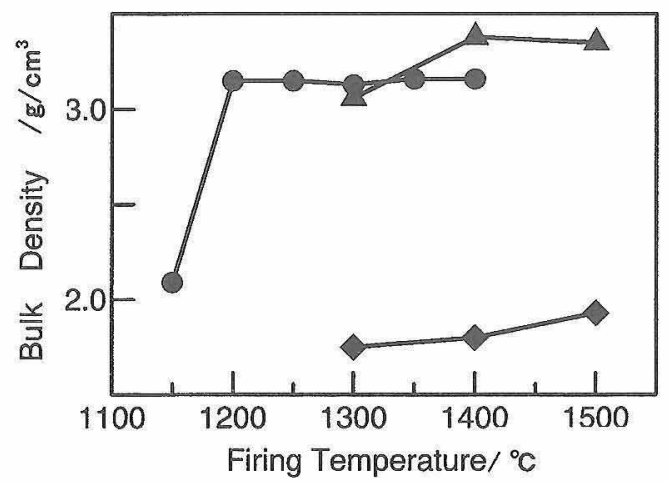

Fig. 1. Bulk densities of sintered $0 \%(\bullet), 5 \%(\Delta)$ and $20 \%(\bigcirc)$ specimens. the residual glass melted at $\sim 1050^{\circ} \mathrm{C}$. This result indicates that the formation of a liquid phase at $>1050^{\circ} \mathrm{C}$ played an important role in the densification. The liquid phase is necessary for the dissolution of fluorine. ${ }^{10)}$ In addition, rearrangement of the particles and dissolution-precipitation through the liquid phase promoted densification. The viscosity of the liquid phase must be sufficiently lowered at higher temperatures to allow the liquid to spread throughout the entire specimen by capillary force. Therefore, as the amount of additive glass decreased, the composites were densified at higher temperatures than the liquid-phase formation temperature of $\sim 1050^{\circ} \mathrm{C}$.

A comparison of the spinel/mica composites obtained in this study with those obtained in the previous one ${ }^{9)}$ is shown in Table 1 . The $20 \%$ specimen of the present study was densified at a lower temperature than that of the previous study ${ }^{9)}$ in which the spinel powder was used as raw materials. The densification is generally impeded when volume expansion, which is caused by the reaction between raw materials, occurs during sintering. Although, in the $20 \%$ specimen of the present study, the volume expansion was caused by reaction between the alumina and the magnesia in the temperature range from 900 to $1200^{\circ} \mathrm{C}$, the densification was promoted. In such a temperature range, the liquid phase was formed as well as the volume expansion. The liquid phase allows the particles to rearrange and pack more closely. Such a rearrangement occurred in both the present study and the previous one. Moreover, the microstructure to be shown later in Fig. 2(c) demonstrates that the particle size of spinel formed in the present study was almost the same as that $(0.3 \mu \mathrm{m})$ of spinel powder used in the previous study. Additionally, the preparation method was the same for both studies, except for the raw materials of spinel used. Therefore, the low-temperature sintering of the present study resulted from volume expansion under the existence of the liquid phase. Probably, under the existence of the liquid phase the volume expansion (i.e., volume increase)
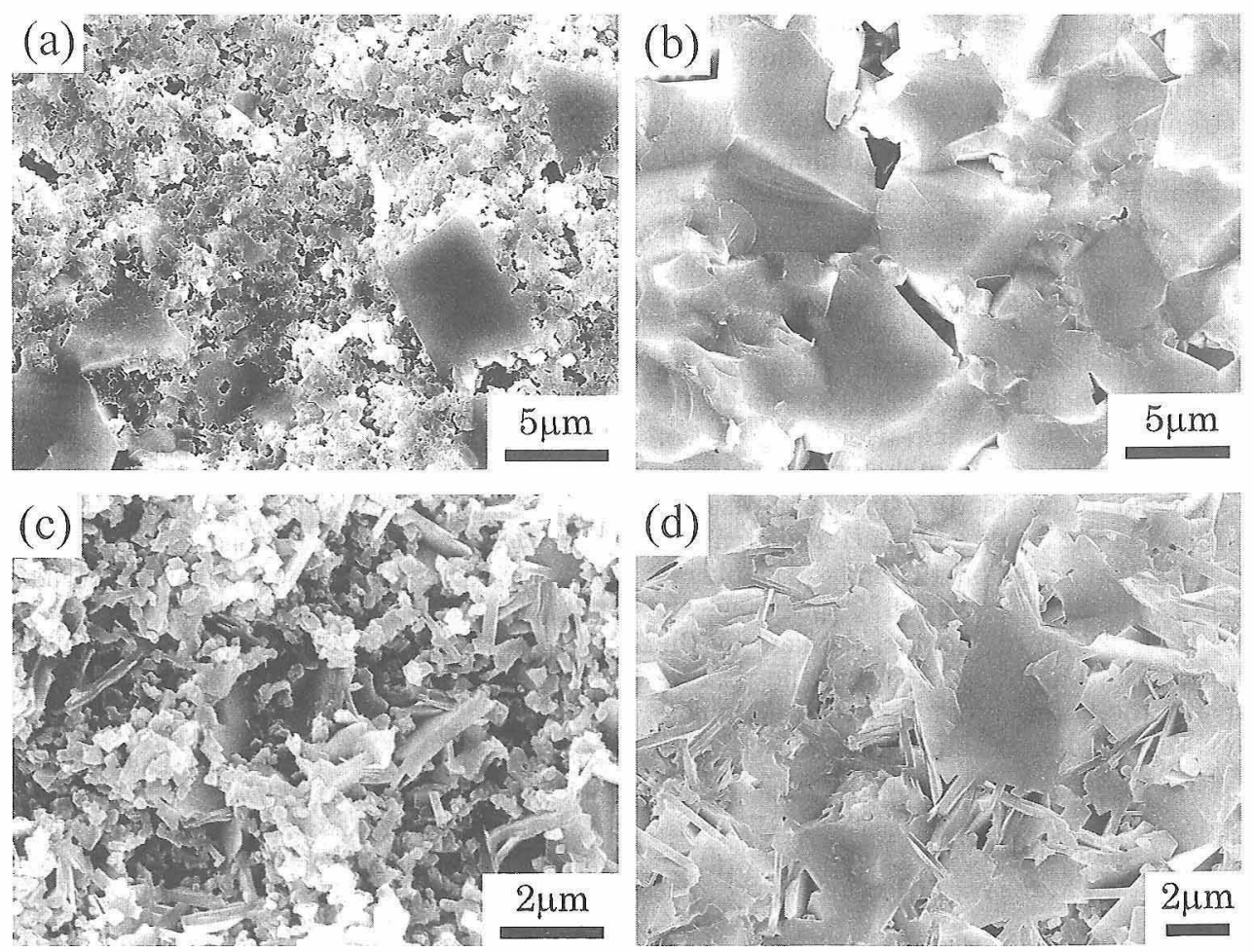

Fig. 2. SEM micrographs of fracture surfaces of $5 \%$ specimen sintered at (a) $1300^{\circ} \mathrm{C}$ and (b) $1400^{\circ} \mathrm{C}$, and $20 \%$ specimen sintered at (c) $1150^{\circ} \mathrm{C}$ and (d) $1200^{\circ} \mathrm{C}$. 
Table 1. Comparison of Spinel/Mica Composites Obtained in This Study with Those Obtained in a Previous Study ${ }^{9)}$

\begin{tabular}{|c|c|c|c|c|c|}
\hline $\begin{array}{l}\text { Spinel raw } \\
\text { materials }\end{array}$ & Specimen & $\begin{array}{c}\text { Densification } \\
\text { temperature } /{ }^{\circ} \mathrm{C}\end{array}$ & $\begin{array}{c}\text { Relative } \\
\text { density / \% }\end{array}$ & $\begin{array}{c}\text { Bending } \\
\text { strength / } \mathrm{MPa}\end{array}$ & $\begin{array}{c}\text { Post-indentation } \\
\text { bending strength / } \mathrm{MPa}\end{array}$ \\
\hline \multirow{2}{*}{ Spinel $^{9)}$} & $5 \%$ & 1400 & 96.8 & $278 \pm 9$ & $176 \pm 26$ \\
\hline & $20 \%$ & 1300 & 94.5 & $266 \pm 15$ & $206 \pm 10$ \\
\hline \multirow{2}{*}{$\begin{array}{l}\text { Alumina and } \\
\text { Magnesia }\end{array}$} & $5 \%$ & 1400 & 96.7 & - & - \\
\hline & $20 \%$ & 1200 & 95.4 & $200 \pm 12$ & $188 \pm 9$ \\
\hline
\end{tabular}

prompted the particle rearrangement and/or filled space (pores). Consequently, the volume expansion acted effectively for the densification, like a closer packing of particles, through the liquid phase. On the other hand, the densification temperatures of the $5 \%$ specimens showed the same value in the present and the previous studies. Because the $5 \%$ specimens did not have a sufficient amount of liquid, closer packing of particles under the existence of the liquid phase, which was mentioned above, did not occur efficiently.

SEM micrographs of the fracture surfaces of the $5 \%$ and the $20 \%$ specimens are shown in Fig. 2. Extended growth of some spinel grains was observed in the $5 \%$ specimen sintered at $1300^{\circ} \mathrm{C}$. Because a small amount of liquid phase was distributed nonuniformly at lower temperatures in the $5 \%$ specimen, some spinel grains grew rapidly in areas with much liquid-phase. In both the $5 \%$ specimen sintered at $1400^{\circ} \mathrm{C}$ and the $20 \%$ specimen sintered at $1200^{\circ} \mathrm{C}$, the spinel grains grew to several micrometers. These microstructures indicate that dissolution-precipitation through the liquid phase highly promoted sintering. In the 20\% specimen, numerous flakelike mica crystals with several micrometers, separated out in the interparticle regions of the spinel. On the other hand, little solid sintering of spinel occurred at $1200^{\circ} \mathrm{C}$. As these results indicate, contact among spinel grains in the $20 \%$ specimen was less than that in the dense spinel/mica composites obtained in previous studies. ${ }^{7)-9)}$

\subsection{Contact damage}

The bending strength of the 20\% specimen was lower than that of the spinel/mica composites obtained in the previous study ${ }^{9}$ ) (Table 1 ). This difference resulted from less contact among spinel grains in the $20 \%$ specimen of this study, as just mentioned. The strength was slightly decreased by Hertzian indentation. This small deterioration implies that the $20 \%$ specimen had flaw tolerance.

Optical micrographs of Hertzian indentation damage and the failure origin site of the post-indented $20 \%$ specimen are shown in Fig. 3. Although a small crack, which was part of the ring crack, and an undeveloped cornlike crack, were observed at the surface and in the fracture surface, a residual depression was formed at the surface. This Hertzian indentation damage shows that both brittle and quasi-plastic damage modes were competing in the $20 \%$ specimen, according to the reports ${ }^{11)-16}$ on the contact damage by the Hertzian indentation test. The fracture site in the post-indented specimen was the cornlike crack. However, quasiplasticity prevented catastrophic failure from the cornlike crack.

\section{References}

1) Bailey, J. T. and Russel, R. R., Jr., J. Am. Ceram. Soc., 47, 1025-29 (1968).

2) Kostic, E., Boškovic, S. and Kiš, S., J. Mater. Sci. Lett., 1, 507-10 (1982).

3) Lepkova, D., Baatarjav, A, and Pavlova, L., Int. Ceram., 42,
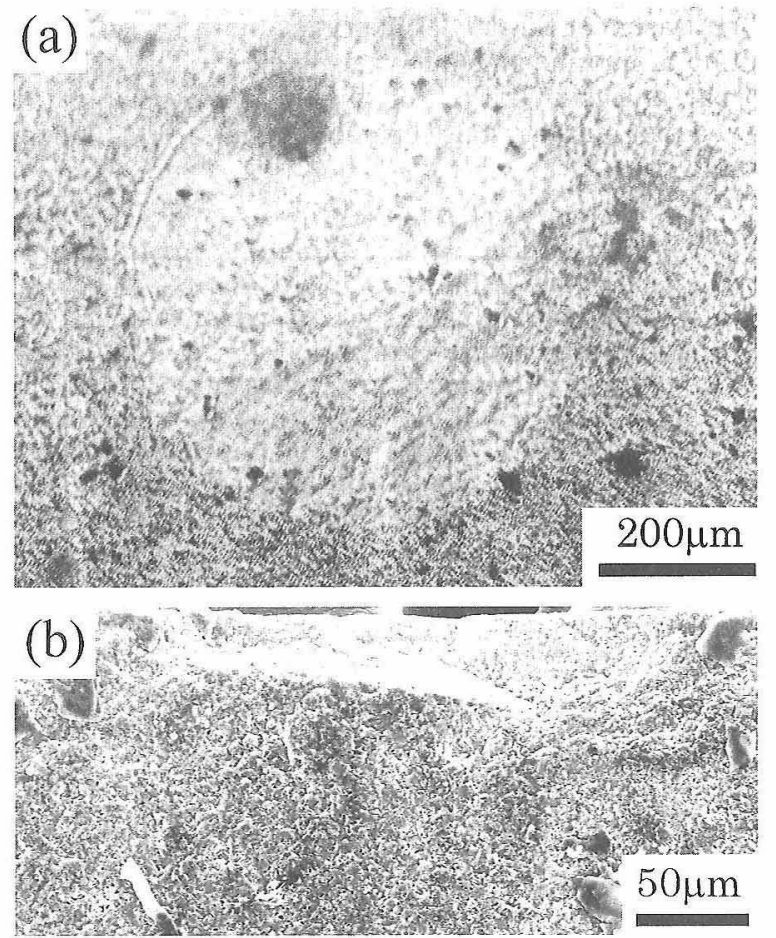

Fig. 3. (a) Optical micrograph of post-indented surface and (b) SEM micrograph of post-indented fracture surface of $20 \%$ specimen sintered at $1200^{\circ} \mathrm{C}$.

89-92 (1993)

4) Sarkar, R. and Bannerjee, G., J. Eur. Ceram. Soc., 20, 2133-41 (2000)

5) Bratton, R. J., J. Am. Ceram. Soc., 57, 283-86 (1974).

6) Hing, H., J. Mater. Sci., 11, 1919-26 (1976).

7) Suzuki, S. S., Taruta, S. and Takusagawa, N., Korean J. Ceram., 4, 363-67 (1998).

8) Suzuki, S. S., Taruta, S. and Takusagawa, N., J. Ceram. Soc. Japan, 108, 548-53 (2000).

9) Suzuki, S. S., Taruta, S., Kitajima, K. and Takusagawa, N., J. Ceram. Soc. Japan, 108, 1079-84 (2000).

10) Hirai, S., Murakami, H. and Katayama, G. H., J. Jpn. Inst. Met., 55, 166-71 (1991) [in Japanese].

11) Latella, B. A., O'Connor, B. H., Padture, N. P. and Lawn, B. R., J. Am. Ceram. Soc., 80, 1027-31 (1997).

12) Peterson, I. M., Pajares, A., Lawn, B. R., Thompson, V. P. and Rekow, E. D., J. Dent. Res., 77, 589-02 (1998).

13) Lawn, B. R., J. Am. Ceram. Soc., 81, 1977-94 (1998).

14) Jung, Y.-G., Peterson, I. M., Pajares, A. and Lawn, B. R., J Dent. Res., 78, 804-14 (1999).

15) Jung, Y.-G., Wuttiphan, S., Peterson, I. M. and Lawn, B. R., J. Dent. Res., 78, 887-97 (1999).

16) Rhee, Y.-W., Kim, H.-W., Deng, Y. and Lawn, B. R., J. Am. Ceram. Soc., 84, 561-65 (2001). 